\title{
Global Englishes Constructs in Language Teaching: A Review of Facebook Materials Marghoob Ahmad \\ $\mathrm{PhD}$ Scholar, Department of Linguistics, The Islamia University of Bahawalpur, Pakistan marghoob.hmd@gmail.com \\ Dr. Mamuna Ghani \\ Director, Executive Training Center (ETC) The Islamia University of Bahawalpur, Pakistan drghani2009@yahoo.com
}

\begin{abstract}
The rising paradigm of Global Englishes (GE) was faced with native-speaker norms and the principle of diversity therein called upon global contents when there was paucity of globallyoriented language materials and typical models hardly meet the future demands of language learners in Pakistan. At the state-level, many varities of Englishes were not in priority list of legislation. In this scenario, this study was a systematic review of Global Englishes constructs operating in facebook materials. Twenty-five facebook posts of different Englishes were selected opting judgmental sampling and axial coding was affixed to analyse thematic patterns in data. Findings evinced the function of GE constructs coalesced in facebook material, and this bonding directed to shape comparative cultural topics for GE instruction which was a joint venture limelighting the deep concerns of L2 speakers assailing L1 cultural, social and economic hegemony Global Englishes-informed instruction was a useful approach to develop linguistic proficiency of students, and facebook materials were a good source to plan diverse Englishes and their constructs for prospective students in Pakistan. American English, British English, New Zealand English, Pakistani English, Thai English, and Indian English were dissected in a review of facebook materials which could be integrated in language teaching. The study was useful in developing an insight into GE constructs to be a source of cross-cultural knowledge helping to nurture multilingual speakers. The synthesis suggested an action plan for Content and Language Integrated Learning (CLIL) in line with inclusivity of GE as a teaching paradigm.
\end{abstract}

Keywords: CLIL, Facebook Materials, Global Englishes Constructs, A review, Language Teaching

\section{Introduction}

Global Englishes (GE) as inclusive research had affected numerous pedagogical practices (Cameron \& Galloway, 2019) and its demand was rising fast across the world. To be 
a ground-breaking move in language teaching, the adaptation of GE as a teaching paradigm was very high among multilingual teachers. Galloway \& Rose $(2019 ;$ p.10,13) called upon it a new shift founded on the theoretical impressions from Englishes worldwide. World Englishes (WE) began as a linguistic and sociolinguistic school of study in the 1970s and 1980s linked primarily with the codification of linguistic variation with special interest in Englishes of former British colonies because Englishisation and globalization escorted an emergence of educational policies globally in regions possessing no historic bond to English-speaking nations.

In consideration of Galloway and Rose (2019; p.6,7) GE perspective overlapped with the ideologies of translanguaging showcasing linguistic hybridity and helped to inform our understanding of how speakers of English as a global lingua franca used their multilingual or translingual repertoires for communication drawing on all of their linguistic resources. The centrality of flexible norms in GE frames resonated with recent work on transnational mobility. (see i.e. Guo \& Maitra, 2017; p.80) The use of global lingua franca continued to shape directions towards pedagogical concerns by offering possibilities for breaking free from fixed native-speaker's norms (see i.e. Rose, Mckinley and Galloway, 2021; pp. 157-189).

Ortega (2013) was of the firm view that multilingual turn impacted the field with a similar magnitude as the social turn in the 1990s contemplating SLA to move away from its cognitive and positivist origins incorporated more social, individualistic and non-traditional perspectives in SLA. Thus, multilingualism also challenged previous conceptions of SLA within wider fields (review i.e. Galloway \& Numajiri, 2020; p.121). However, teacher education was the key factor in ensuring sustained innovation in diverse materials on the need for transformative change in language teaching with regard to ELF as reported by Dewey \& Patsko (2018; p.441). Kirkpatrick (2012; p.121) truly claimed that a multicompetent English teacher was far more suitable role model for learners than a monolingual native speaker, and within a GE perspective, the transnational prospect of GE sat with transnationalism and like ELF summoned the inflexible boundaries of languages.

Widdowson (2012, p.3) reckoned more innovations for learners that new cultures were making an appearance at full tilt in each instance of language usage particularly in lingua franca contexts where speakers brought contrastive expectations and experiences to the speech community. Students benefited from more fluid, diverse and multiple forms of the language instruction and some of this fluidity could be gained through the exposure of Englishes while 
diversity could also be attained through awareness raising. In the later of these studies, an explicit pedagogical task involving debate over Singlish and the Speak Good English Movement in Singapore sustained to shape students and their standard language ideology.

GE as a teaching paradigm configurated the role of globally-oriented language materials in the 'internationalized' and 'Englishized' higher education. Galloway and Rose (2021; p.33) truly affirmed that global contents had to impart by language teachers to support the students. The innovation in language teaching materials was a complex process and without inclusive research in multiple contexts, it was onerous to evaluate whether the goals could be achieved in view of Galloway \& Ruegg (2020).

Galloway \& Numajiri (2020, p.121) candidly reported that Global Englishes-related newness in materials had to administer through teachers' professional training, and for sustained progress, preservice and in-service teachers were to ensure adoption of Global Englishes materials by exchanging knowledge of their chosen variety. Galloway and Rose (2018; p.14) also accurately affirmed that by listening to their classmates' presentations, the task raised students' awareness of variation in English, and attitudes of students differed from standard models presented in typical language material in Japan, and they were of the convinced opinion to evaluate an innovative pedagogical task to raise awareness of Global Englishes and to summon standard language ideology in an English language classroom (see i.e. Rose \& Galloway, 2019; p. 10,13).

Thus, any evaluation of language materials in respect of GE had flexibility in terms of tasks, activities and operations. An assessment of materials needed to enter on what was implied in terms of pedagogical beliefs. Both Galloway and Rose (2019; p.9) firmly agreed with the want for cross-cultural materials to meet the demands of English learners who communicated more with other non-native speakers than with native speakers of English. Syrbe has accomplished her exploratory analysis of four major textbook series via an adapted GE framework. Masuhara and Tomlinson also assessed textbooks in United Kingdom claiming GE to be used for materials' research for practioners and it also resembled a close-look evaluation. GE orientation was used to examine textbooks at a practical level, and was intended for practioners' levels where the assigned score was used for ranking and an evaluation method was applied in place of a more rigorous method for practioners as the three-step evaluation exactly recommended by Galloway (2018; p.3) who opted a second procedure of in-depth analysis which used specific and countable features of the textbook as proxy measures for a 
larger construct. In order to show how GE as an inclusive research was utilized to elicit other types of data within textbooks. It followed methodological epistemologies of content analysis and this was similar to analysis conducted by Syrbe.

A good GE material portrayed culture as created in communities of practice, and learners did not join an English-using culture but co-creating it. Galloway (2018; p.14) exactly noted that material writers were encouraging to draw on such opportunities for learners to reflect on their encounters how communication between those from diverse lingua-cultural backgrounds differed to predetermine native English speaker norms. In consideration of Galloway and Rose (2019; p.10) GE constructs discerned the value of not only hiring qualified teachers regardless of native status but also what teachers of different L1 could bring to learners, and so on spotted a need to draw upon a wider range of sources from global usage of English language today, however, ELT industry was still propped up by Anglocentric publications, and both further truly believed the need to perceive learners' linguistic repertoire as an extremely important resource for learning. Accordingly, the wanted change to move away from traditional materials of ELT to a GE contents was a speedy alteration in how we conceptualized students' wants in multilingual classroom. Thus, it was central to a paradigm shift in English language teaching which was an accurate move in assessment perspectives by which outcomes of GE instruction were measured. Ergo, Galloway and Rose (2019; p.7) steadily noted that GE as a teaching paradigm was not proposed as a superior approach but it summoned the assumptions about English that pervaded into teaching practices, and saturated teaching materials by permeating into the ideologies of learners and called for a re-evaluation of current practices in the light of the changing sociolinguistic usage of the language.

GE emphasized awareness activities of language variation including register and genre variation and its courses aimed at nurturing students' control over dominant writing norms, diversity of language, and openness to nondominant forms (review i.e. Tardy, Reed, Slinkard \& LaMance, 2020). With GE contents, students developed tolerance for language diversity comprehending the angles that other varieties were practically hybridized or dehegemonized across nations. (see i.e. Boonsuk, Ambele \& McKinley, 2021) Thus, in describing the function of language materials, BNCC serialized the necessary competences, skills and contents to be covered in the curriculum, which were organized into five pillars: orality, reading, writing, linguistic knowledge and intercultural dimension. Apart from the well-known language skills of reading and writing, orality encompasses listening, oral interaction and oral production. 
Linguistic knowledge is expanded into grammar and vocabulary, and the last pillar intercultural dimension deals with interculturality from an ELF perspective. A digitally-enhanced learning context creates a number of possibilities for English learners to express their ideas, feelings and values as propounded precisely by Franco (2021, p.63).

Thus, in GE context, language materials imparted the target language culture and incorporated multiple international cultures, because it would assist learners to negotiate their understandings of the interlocutors' values, and largely influenced their cognition and affective attitudes toward themselves, other people and society. (review i.e. Franco, 2021; p.63) Language materials had to address different voices and cultural perspectives to enable English learners to figure out different cultural values. From the EIL perspective, textbooks also had to integrate a diversity of English learners' racial and cultural backgrounds by empowering them to identify various voices. The current language materials did not pay sufficient attention to incorporate different cultural values in multiple cultures and were strictly limited to native English-speaking cultures. Textbook writers were to consider the variability by helping learners to utilize their familiar cultural experiences and facilitated their identification with varieties of English (see i.e. Franco, 2021; p.63). Carrillo and Flores (2020) noted the need for a comprehensive view of pedagogy that integrates technology to support teaching and learning. Similarly, Onyema et al. (2020) examined the impact of Covid-19 on language instruction in different countries. Planning a language material is a systematic way of designing, executing, and evaluating the whole process of research and learning to use specific goals, utilizing research findings in human communication, and employing a combination of human and nonhuman resources to create more effective learning. (e.g. see Rahmati, Izadpanah, \& Shahnavaz, 2021) Language material was an attempt towards inclusivity reflecting multicultural views, and could perpetuate a culture learning and otherwise of discrimination and social exclusion. By identifying the need for an alternative approach, one had to focus on inclusion and diversity. (see i.e. Bollas, 2021) The more pragmatic materials in English textbooks were pivotal since they were the major references used in classroom whether the pragmatic content as required in the curriculum was fulfilled. (see i.e. Siswantara and Ariffin, 2021), the local and neutral culture topics had functioned as templates to contextualize target and global cultures in language teaching classrooms in order to develop students' intercultural awareness of local, target, and global cultures. (see i.e. Marwa, Cahyono, Latief, \& Prayogo 2021) The implications of the actual use of English in China's workplace for language teaching reform in 
the context of English as a lingua franca (ELF) had to gear towards using English communicatively. Language teaching curriculum and pedagogies had to focus more broadly on improving students' communication skills instead of narrowly measuring whether they had successfully adhered to lexico-grammatical accuracy pertaining to Standard English norms. The native-speaker-based pedagogical model of language teaching would have enriched judiciously selected indigenized variants as long as meaning was not adversely affected. Language reforms were absolutely crucial to ensure a steady supply of properly trained and resourceful language teachers. (see i.e. Deyuan He, David CS Li (2021).

On this account, we had contributed to fill this critical void in literature, and in the light of multifarious angles that tend to promote GE instruction with multilingual language materials, we had tried to explore GE constructs operating in facebook materials. It was deeply important to investigate how successfully facebook materials could be used in GE instruction in the setting of Pakistani classrooms. Many rural \& urban students had no ingress to GE instruction impeding their productivity (Ahmad, Ghani, Malik, 2020). Therefore, this study attempted to explore Global Englishes constructs operating in facebook materials. The study addressed the following research questions:

\section{Research Questions}

- What are Global Englishes constructs operating in facebook materials?

- What are the implications of facebook materials for language teaching?

\section{Research Methodology}

Qualitative paradigm was set in motion to explore Global Englishes constructs operating in facebook materials. The key informants were facebook posts (FP) sampled on the basis of researcher's own judgment. The context differed in meanings. Our inclusion criteria for facebook posts was that it must be a post from Englishes worldwide. It must be a facebook post in the year 2020-2021. Macaro's method of systematic review was adopted with the aim to develop language materials for GE instruction. In total, this procedure identified twenty-five facebook posts from different Englishes. In analysing data, lexical items were decoded for thematic patterns and global contents were dissected from facebook materials. Axial coding was applied for meaning, events, reality, and activities. Categories surfacing repeatedly were interconnected and findings had been connected with research objectives. (Ahmad, Ghani, Malik, 2020) In data analysis, questions were addressed as an illustration what was the unit of text in data? Who was centrally acting therein? What were the main activities in data? Where 
were links in data? In interpreting data, meanings were found to answer questions in findings and connections were seen in data pieces. Data was interpreted by addressing four questions. What was deeply important in data? Why was it significant? What was to be learned from it? So, what? The facebook data was selectively transcribed which revealed a number of constructs related to GE. Lexical items loaded with global contents were coded, categorized and analysed. A set of themes surfaced which directed us to shape diverse topics for GE instruction paving the way to chalk out an evidence-driven advice about Global Englishes-informed instruction using multilingual materials from facebook. Both results and findings had been discovered from facebook data and discussion and conclusion parts were reported. (Gay, 1996)

\section{Data Analysis}

(F.P-1)

My Christmas in a War zone

Christmas in Vietnam was like another day with the exception of warm food, powdered potatoes, canned Turkey, extra C-rations, and home-made hooch (Fermented dried fruit turned alcohol). Mail was a rare treat given the fact that it rarely arrived. Care packages came from nice mothers and was shared by the recipient often willingly. Fizzies (a wafer you dropped into stagnant water) was a real treat killing the awful taste of canvas confined aqua. No. Christmas was just another day for the third Marine Amphibious Force. We lived hard and we were Spartans. Tough conditions made for tough warriors we lived

(Steve Gotlieb)

The lexical items in data set reflects usage of American English as powerful Inner Circle variety. The signifiers "celeberating Christmas in Vietnam; warm food; powdered potatoes; C-rations; home-made hooch; care packages from nice mothers; \& Marine Amphibious Force" are really important in this facebook post. They have signified the challenging living conditions made for tough U.S warriors in war zone. All Christian pupils and teachers in universities are engaged in it. The main reality in these signifiers is allusion to Vietnam cause and celebration of Christmas by warriors in war. Findings include trends in Vietnam, needs, effects, conditions and treatments of soldiers for whom Christmas day is to be wished and enjoyed like any other day with warm eatables for soldiers living hard as they are Spartans and it is linked with problem and questions of study. Necessary provisions are needed 
to incorporate these Global Englishes constructs available in facebook materials as an innovation in curriculum for developing students' linguistic competency through American English and the same denotes valuable implications to equip students on peculiar American cultural traits and complexes.

\section{(F.P-2)}

The Temples...Churches...\& Mosques are closed since eight months......... those who survived. those who succumbed.

Even God creates his own plan...... who knows...who is next? (Bidhunandan Dash)

The lexical items from data set demonstrates the usage of Indian English by a speaker exposing a condition of lockdown during Covid-19. The signifiers "closed churches, mosques, temples; survived; succumbed; God; \& who is next?" are really important in this post, and they have signified a complete closure during deadly pandemic. Religious institutions have stopped performing their functions. Some people are the victims of deadly virus, others have luckily been survived during pandemic. Man is destined to be a puppet having no choice of his own in Indian mind set and nobody knows about his turn when it is coming. All social activities are under strict lockdown in pandemic. Finding demonstrates global constructs in data i.e. religious institutions, different religions, powers of god, life \& death during a pandemic are explicitly connected with research problem and questions. The global constructs within Indian English is a gateway of cultural materials which can be integrated in Global Englishes-informed syllabus for teaching multilingual students. Provisions are needed to be made about global contents from Indian English available on facebook in order to develop multicompetent speakers by language teachers. Global constructs operating in Indian English implicate greatly the usage of its cultural materials as teaching topics for prospective language learners in multilingual classrooms.

(F.P-3)

Atleast something positive in the dark days of Covid-19. By the grace of Allah, I managed to arrange PhD Public Defence of Noveen Javaid who has been declared now Dr. Noveen Javaid by the external examiners. I congratulate her and Dr. Sohail Saeed and the little Master Abdullah. I 
UNIVERSITY OF CHITRAL JOURNAL OF LINGUISTICS AND LITERATURE VOL. 5 | ISSUE I | JAN - JUNE | 2021

am glad to share that $5 \mathrm{PhD}$ faculty members are serving in the department of English Linguistics. Out of 5,4 members are my supervisees. My special thanks to Dr. Habibullah Pathan, and Dr. Samina Sarwat for sparing their time to be the examiners for today's event. I am grateful to Allah Subhanallah TaAlla that He enabled me to serve my nation and country. (Mamuna Ghani)

In this data set, lexical items show the usage of Pakistani English by a speaker manifesting academic activities in PhD Public defence during Covid-19. The signifiers "Allah Subhanallah TaAlla; positive; dark days; $\mathrm{PhD}$ public defence; external examiners; little master; $\&$ faculty members" are really important in this post, and they signify speaker's tribute to God who is all powerful and seeks divine inspiration in accomplishing the activities of $\mathrm{PhD}$ public defence. Universities, teachers and students are mainly engaged in this activity. The major reality in signifiers is university preparedness plans which answer research question and problem. The academic activities in $\mathrm{PhD}$ public defence programme have been influential in Pakistani English and a rich academic manifestation, and from facebook materials, these Global Englishes constructs can be integrated in language curriculum for multilingual students in face-to-face or digital teaching by instructors. Provisions are also direly needed about instructional materials available in Pakistani English on facebook to be made by universities and $\mathrm{PhD}$ public defence related facebook topics have profound implications for language learners in Pakistan.

\section{(F.P-4)}

Alhamdulillah, ended with memorable accomplishments, the English proficiency development session for students at Islamic Studies Demonstration School was organized to cultivate quality global citizens amid linguacultural diversity. The training session entitled: "English Language Learning in the $21^{\text {st }}$ Century: A Route to Global Citizenship" Lasted four days. Throughout these days, the students had the opportunity to learn English through a variety of activities aligned with the enhancement of necessary $21^{\text {st }}$-century skills, including teamwork, problem-solving, critical thinking, global awareness, and respect for and acceptance of linguacultural diversity. (Yusuf Joseph) 
In this data set, the lexical items represent Thai English serializing academic activities executed in English proficiency sessions. The signifiers "Alhamdulillah; English proficiency; global citizens; linguacultural diversity; $21^{\text {st }}$-century skills; team work; problemsolving; critical thinking; \& global awareness" refer to diverse \& global materials which can be used for the purpose of nurturing multicompetent speakers in a society. Universities, teachers and pupils are centrally engaged in sifting global materials. The major activity in these signifiers is capacity building through English proficiency activities for ESP learners in Thai English. Finding is the capacity building for quality progression in Thai English usage which is connected with research question and problem. Global constructs in Thai English is a rich source of cultural learning which can be incorporated in syllabus by language teachers for developing English proficiency of ESP learners in Pakistani universities, and the same also has deep-rooted implications for teaching Thai English to ESP learners of Pakistan in order to make the prospective students as global citizens within Pakistan.

\section{(F.P-5)}

So, after the end of the Chinese New Year celebration and break, our spring semester is actually starting today ( 2 March). However, we are still not on campus, as instead we were advised to stay put in our home countries until further notice and do our teaching and other work online (you know, because of the virus). Attending the webinar 'Adapting quickly to teaching online' (offered by one of the departments of the University of Harvard) right now. Very useful, you can attend it too. (Bill Batziakas)

In this data set, the lexical items used by a speaker from British English are showing academic activities in English language teaching and learning online during Covid-19. The signifiers "Chinese New Year; spring semester; work online; virus; \& webinar" are really important because they signify teaching and learning online during Covid-19. Universities, teachers and pupils are centrally engaged in it. Finding is the capacity of teachers engaged in online mode of teaching to language learners which is connected with research question and problem, and British English is adopted as a native model by language teachers in outer and expanding circles. So, Global Englishes constructs in facebook material available online are a 
cultural treasure which can be exchanged through British English adaptations and the same can be integrated in syllabus for language teaching to ESP learners and it has greater implications for developing linguacultural diversity among ESP learners of Pakistan.

\section{(F.P-6)}

I've never been a very community-minded person-I suppose I've never felt I had much I could offer to others. But more and more I think community is vitally important-amongst the turmoil produced by Covid, the rise of extremist right-wing groups, climate change, polarization in the distribution of wealth-I see people doing good things, unselfish things, helping others. I want to help others too, but I have been unsure how to go about this.

Then I thought one thing I know a bit about- I 've been teaching it at university for many years-is creative writing. I have a $\mathrm{PhD}$ in it, I have a couple of books, I publish poems, book reviews, essays. So maybe I can help people with that. If you are an aspiring writer, or a published writer, and you have some poems, or short stories, maybe a novel or a collection of essays that you want help with, I'm here for you. (Tim Upperton)

In this data, the speaker uses New Zealand English to show his determination to help the community people amid Covid-19 with rich creative writing skills. The signifiers "Community-minded; Covid turmoil; extremist right wing; climate change; polarization; wealth distribution; unselfish things; helping others; creative writing; publishing poems; book reviews; essays; short stories; \& writing novels" are deeply important and they signify community service, pledged by the speaker who is $\mathrm{PhD}$ in creative writing, during Covid-19 pandemic. People engaged in community service are centrally engaged in it. The major activities in these lexical items are community service and creative writing activities for ESP learners using New Zealand English, and the same as inner circle variety is associated with research question and problem. Teaching creative writing to ESP learners through New Zealand English has greater implications in Pakistan. Teachers and universities are direly needed to make necessary provisions for using Global Englishes constructs operating in 
facebook materials available online from New Zealand English for developing linguistic proficiency of ESP learners with in Pakistan.

\section{Results and Findings}

We have identified Global Englishes constructs operating in facebook materials during data analysis, and the comparative cultural topics can be serialized in table of specification charts with measurable objectives by language teachers. We have observed the constructs of American English in facebook materials i.e. celeberating Christmas in war, benefits of warm food, eating powdered potatoes, C-rations in U.S military, importance of care packages from nice mothers, and understanding Marine Amphibious Force. We have noted global topics in Indian English i.e. closed temples, churches \& mosques, life, death, and God's plans. We have perceived global issues in Pakistani English i.e. Positivity, dark days of Covid, importance of $\mathrm{PhD}$ public defence, roles of external examiners, religion and teaching. We have identified global themes in Thai English as English proficiency, global citizens, linguacultural diversity, $21^{\text {st }}$ century skills, team work and global awareness. We have explored constructs in British English such as Chinese new year, spring semesters, working online, Covid-19 virus and webinars. We have also got an insight of global constructs moving in New Zealand English like community-minded people, turmoil of Covid-19, climate change, polarization, wealth distribution, helping others, creative writing, publishing poems, and book reviews. We have also perceived the reported contentions of Pennycook (2007) who has adduced the diversity of English rapidly increasing around the world, and the strong views of Ortega (2013) have highlighted multilingual turn overlapping with Global Englishes frames which are calling for a sharp transformation in ELT. In our quest for Global Englishes constructs from a systematic review of facebook material, we have also diagnosed accentuating Global Englishes moves asking for a dire need to break away from practices of presenting constant regional cultures in textbooks as contexts for language learning by hands of language teachers. The central reality is Global Englishes approach in ELT which is not an alternative step but an ideology used to inform rather than direct teaching in twenty-first century. For students' learning and teaching English through online mode or face-to-face instruction, we have observed a dire need for teachers to choose Global Englishes ideology for language instruction, and universities to execute provisions regarding IT tools for application of Global Englishes theory to multilingual 
students in Pakistan and the same can prove to be a healthy activity to play and progress with Global Englishes approach.

\section{Discussion and Conclusion}

We have discovered issues of Content and Language Integrated Learning (CLIL) and perceived ways to maximize Global Englishes-informed language teaching with limitations. We have also believed widely to incorporate these identified constructs in Global Englishesinformed curriculum during face-to-face or digital teaching to multilingual students. The frames of world Englishes i.e. American English, British English, New Zealand English, Pakistani English, Thai English and Indian English are observed in facebook materials that can easily be integrated in Global Englishes-oriented teaching. Global Englishes constructs have been fascinating for Englishisation of Higher Education in Pakistani universities, and the endpoint is provisions to be made by language planners by codifying Global Englishes as an inclusive research and teaching paradigm by opting multicultural topics from many Englishes available on facebook in order to develop multicompetent speakers in Pakistan. Galloway (2011, 2013) has asserted Global Englishes to be a sounding shift in curriculum. Galloway \& Rose (2019) have also contended that English is being accorded the status of a foreign language due to the reasons of globalization and intra-national usage. Kumaravadivelu vocalizes an epistemic break calling on present practices ill-fitting in ELT. For rural \& urban students of Pakistan, the lacking of access to Global Englishes instruction impedes their productivity (Ahmad, Ghani, Malik, 2020). Canagarajah and Garcia have believed overlapping of Global Englishes with translanguaging. The multilingual turn also strongly overlaps with Global Englishes calling for a transformation in ELT and akin calls have been cropping up within SLA reported by Ortega (2013). An uncontroversial segment of wanted change to move away from traditional approaches thereof ELT to a Global Englishes set up is a speedy transposition in how we conceptualize students' wants in language classroom, Global Englishes perspective does not look for a replacement of one standard with another and is not proposed as a superior teaching approach but it summons the assumptions about English that pervade into teaching practices and saturate teaching materials by permeating into the ideologies of learners. The findings of this study suggest that Global Englishes-informed instruction has been a useful approach to develop linguistic proficiency of students on a large scale, and facebook materials are a good source to plan diverse Englishes and their constructs for multicompetent students in 
Pakistan. It can minimize digital divide and inequality. The suitable approach to cover limitations of this mode of teaching is to overcome perceived obstacles and to develop preparedness plans along with necessary IT tools. The study implicates a dire need to unfold capacity building of teachers by way of Global Englishes-oriented training to promote globalization and internationalization.

\section{References}

Ahmad, M. Ghani, M. \& Malik, A. (2020). Exploring the Relation between English and Online Mode of Learning during Covid-19. Linguistics \& Literature (LLR) 6 (2): 109116.

Boonsuk, Y; Ambele, A. Eric; McKinley. J. (2021) Developing awareness of Global Englishes: Moving away from 'native standards' for Thai university ELT, System Volume 99, P.1, https://doi.org/10.1016/j.system.2021.102511

Bollas, A. (2021). A critical discussion of inclusive approaches to sexualities in ELT ELT Journal, Volume 75, Issue 2, April 2021, PP. 133-141, https://doi.org/10.1093/elt/ccaa075

Carrillo, C., \& Flores, M. A. (2020). COVID-19 and teacher education: a literature review of online teaching and learning practices. European Journal of Teacher Education, 43(4), PP. 466-487. https://doi.org/10.1080/02619768.2020.1821184

Cameron, A. and Galloway, N. (2019) Local thoughts on global ideas: pre- and in-service TESOL practitioners' attitudes to the pedagogical implications of the globalization of English. RELC Journal, 50(1), pp. 149-163. https://doi: 10.1177/0033688218822853

Dewey, M., \& Patsko, L. (2018). ELF and teacher education. In Jenkins, J., Baker, W., \& Dewey, M. (Eds.), The Routledge handbook of English as a lingua franca, pp. 441455 Abingdon, UK: Routledge. Google Scholar

Deyuan He, David CS Li (2021). Glocalizing ELT Reform in China: A Perspective from the Use of English in the Workplace, RELC Journal First Published July 6, 2021 Research https://doi.org/10.1177/00336882211018499

Franco, C. (2021) Teaching English as a Lingua Franca in Brazil: Insights into Materials 
Writing, International Journal of English Linguistics; Vol. 11, No. 3; P.63, 2021 URL: https://doi.org/10.5539/ijel.v11n3p62

Galloway, N., \& Numajiri, T. (2020). Global Englishes language teaching: Bottom-up curriculum implementation. TESOL Quarterly, 54(1), PP. 118-145. Cross Ref Google Scholar

Galloway, N. and Rose, H. (2021) English medium instruction and the English language practitioner. ELT Journal, 75(1), pp. 33-41. (doi): 10.1093/elt/ccaa063

Galloway, N. and Ruegg, R. (2020) The provision of student support on English Medium Instruction programmes in Japan and China. Journal of English for Academic Purposes, 45, 100846. (doi: 10.1016/j.jeap.2020.100846)

Galloway, N. and Numajiri, T. (2020) Global Englishes language teaching: bottom-up curriculum implementation. TESOL Quarterly, 54(1), pp. 118-145. (doi: $10.1002 /$ tesq.547)

Galloway, N. and Rose, H. (2018) Incorporating Global Englishes into the ELT classroom. ELT Journal, 72(1), pp. 3-14. (doi: 10.1093/elt/ccx010)

Galloway, N. \& Rose, H. (2019). Global Englishes for Language Teaching, Cambridge University Press, pp.3,6,7,9,10,13,17.

Galloway. N. (2011). An Investigation of Japanese Students' Attitudes towards English Unpublished Ph.D. dissertation. University of Southampton, pp.11-17

Galloway. N. (2013). Global Englishes and English Language Teaching (ELT) - Bridging the Gap between Theory Practice in a Japanese Context. System, 41 (3), PP. 786-803.

Galloway, N Rose, H. (2014) Using listening journals to raise awareness of global Englishes in ELT. ELT Journal, 68 (4), 386-96.

Galloway, N Rose, H. (2018) Incorporating Global Englishes into the ELT class room. ELT Journal, 72 (1), pp. 3-4.

Gay, R. L. (1996). Educational Research: Competencies for Analysis and Applications, $9^{\text {th }}$ Edition, pp. 138, 458, 380.

Guo, S. \& Maitra, S. 2017. Revisiting curriculum in the age of transnational mobility: towards a transnational and transcultural framework. Curriculum Inquiry, 47(1), pp. 8091.

Kirkpatrick, A. 2012. English as an Asian Lingua Franca: the "Lingua Franca Approach" and implications for language education policy. Journal of English as a Lingua 
Franca, 1(1), pp. 121-39.

Matsuda, A. 2017. Introduction. In A. Matsuda, ed., Preparing Teachers to Teach English as an International Language. Bristol: Multilingual Matters, pp. 3-18.

Marwa, M; Cahyono, Y.B; Latief, A. M. \& Prayogo, A.J (2021). Intercultural Topics in the Indonesian English Language Teaching Classroom: Contextualizing Local and Neutral Cultures to Target and Global Cultures Journal of Intercultural Communication, 21(1) PP. 34-45

Onyema, E. M., Eucheria, N. C., Obafemi, F. A., Sen, S., Atonye, F. G., Sharma, A., \& Alsayed, A. O. (2020). Impact of Coronavirus pandemic on education. Journal of Education and Practice, 11(13), 108-121. http://doi.org/10.13140/RG.2.2.2 $\underline{7946.98245}$

Ortega, L. 2013. SLA for the $21^{\text {st }}$ century: disciplinary progress, transdisciplinary relevance, and the bi/multilingual turn. Language Learning, 63 (supp.1), pp. 1-24.

Pennycook. 2007. Global Englishes and Transcultural Flows Abingdon and New York: Routledge, p. 529.

Rose, H; McKinley, J; \& Galloway, N. (2021). Global Englishes and language teaching: A review of pedagogical research. Language Teaching, Volume 54, Issue 2, April 2021, pp. 157 - 189 DOI: https://doi.org/10.1017/S0261444820000518

Rahmati, J., Izadpanah, S. \& Shahnavaz, A. A meta-analysis on educational technology in English language teaching. Lang Test Asia 11, 7 (2021). https://doi.org/10.1186/s40468-021-00121-w

Rose, H. \& Galloway, N. (2017). Debating standard language Ideology in the classroom: using the 'Speak Good English Movement' to raise awareness of global Englishes. RELC Journal,48 (3), 29 4-30.

Rose, H. and Galloway, N. (2017) Debating standard language ideology in the classroom: using the 'Speak Good English Movement' to raise awareness of Global Englishes. RELC Journal, 48(3), pp. 294-301. (doi: 10.1177/0033688216684281)

Siswantara, E; Ariffin, K. (2021). Analysing the Pragmatic Content in the Conversation Sections in Indonesian ELT Textbooks, Vol 5 No 3 (2021): International Journal of Modern Languages and Applied Linguistics DOI: https://doi.org/10.24191/ijmal.v5i3.14035

Tardy C. M, Reed. K, Slinkard J.R, LaMance R. (2021) Exploring Global Englishes content 
and language variation in an academic writing course. TESOL J. 2021; 12: e520. https://doi.org/10.1002/tesj.520 Exploring Global Englishes content and language variation in an academic writing course, P.2-3.

Widdowson, H.G. 2012. ELF and the inconvenience of established concepts. Journal of English as a Lingua Franca, 1 (1), pp. 5-26.

Zhang, X; Su, X (2021). A cross-national analysis of cultural representations in English textbooks used in China and Germany, SN Soc Sci A Springer Nature Journal 1:91 https://doi.org/10.1007/s43545-021-00088-8

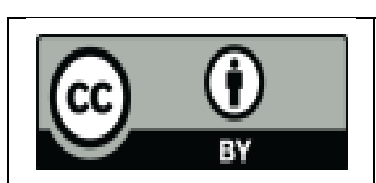

@ 2021 by the author. Licensee University of Chitral, Journal of Linguistics \& Literature, Pakistan. This article is an open access article distributed under the terms and conditions of the Creative Commons Attribution (CC BY) (http://creativecommons.org/licenses/by/4.0/). 